\title{
Role of Different Treatment Modalities in Cavity Volume during the Treatment of Cystic Ecchinococcosis
}

\section{Kistik Ekinokokkozisin Cerrahi Tedavisinde Kullanılan Farklı Yöntemlerin Kist Boşluğunun}

\section{Kapanmasina Etkisi}

\author{
Barış Sevinç¹, Ömer Karahan², Gürcan Şimşek³, Süleyman Bakdık', Nergis Aksoy ${ }^{3}$, Seçil Soydan ${ }^{3}$ \\ ${ }^{1}$ Clinic of General Surgery, Sarıkaya State Hospital, Yozgat, Turkey \\ 2Department of General Surgery, Necmettin Erbakan University Meram School of Medicine, Konya, Turkey \\ ${ }^{3}$ Clinic of General Surgery, Konya Training and Research Hospital, Konya, Turkey \\ ${ }^{4}$ Clinic of Radiology, Konya Training and Research Hospital, Konya, Turkey
}

\section{ABSTRACT}

Objective: Surgery and percutaneous aspiration-injection-re-aspiration (PAIR) are widely accepted treatment modalities for hepatic hydatid cysts. Endoscopic retrograde cholangiopancreaticography (ERCP) acts as a minimally invasive rescue method for the biliary complications of both the hydatid cysts and treatment modalities. The aim of this study was to identify the role of different treatment modalities in the obliteration of hydatid cysts.

Methods: Patients treated for hydatid cysts between January 2009 and December 2013 were evaluated in the study. Data were collected from hospital records. All cyst cavities were evaluated by ultrasonography or computed tomography.

Results: Ninety-five (40.4\%) males and 140 (59.5\%) females were included in the study. Before the procedures, the mean cyst diameter was $89.7 \pm 33.5 \mathrm{~mm}$. At follow-up, the mean cyst diameter decreased to $53.2 \pm 30.1 \mathrm{~mm}$. In the ERCP group, the mean diameter of the residual hydatid cyst cavity was significantly lower than that of the other groups $(p=0.003)$.

Conclusion: ERCP provides faster cyst shrinkage and even disappearance of the residual cavity in $50 \%$ of cases. Moreover, in hydatid cysts with biliary communication, ERCP+ES can be safely used for primary treatment.

Keywords: Liver, hydatid disease, surgery, ERCP, PAIR

Received: 29.11.2015 Accepted: 14.04.2016

\section{Öz}

Amaç: Cerrahi ve Perkütan Aspirasyon Enjeksiyon Reaspirasyon (PAIR) günümüzde karaciğer hidatik kistleri için yaygın kullanılan tedavi yöntemleridir. Endoskopik RetrogratKolanjiopankreatografi (ERCP) ise hem kistin kendisine hem de tedavi yöntemlerine bağlı komplikasyonlar için bir kurtarma yöntemidir. Bu çalışmanın amacı hidatik kist tedavisinde kullanılan farklı yöntemlerin kavite küçülmesi üzerindeki etkisini araştırmaktır.

Yöntemler: Kliniğimizde Ocak 2009 ile Aralık 2013 tarihleri arasında karaciğer hidatik kisti nedeniyle tedavi edilen hastalar çalışma için değerlendirildi. Veriler hastane kayıtlarından elde edildi. Tüm kist kaviteleri ultrasonografi yada bilgisayarlı tomografi ile değerlendirildi.

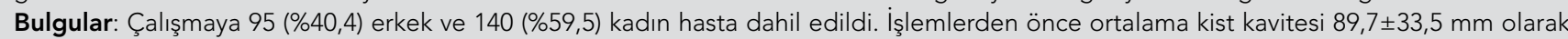
tespit edildi. Takiplerde ortalama kist kavitesi 53,2 $\pm 30,1$ mm'ye geriledi. ERCP grubunda ortalama rezidü kist kavitesi diğer gruplara göre belirgin düşük izlendi $(p=0,003)$.

Sonuç: ERCP ile hidatikkist kavitesinde belirgin azalma hatta hastaların yarısında kavite kaybolması elde edilebilir. Dahası, Biliyer sistemle bağlantılı hidatikkistlerde ERCP ve Endoskopik Sfinkterotomi birinci basamak tedavi olarak güvenle tercih edilebilir.

Anahtar Kelimeler: Karaciğer, Hidatik kist, Cerrahi, ERCP, PAIR

Geliş Tarihi: 29.11.2015

Kabul Tarihi: 14.04 .2016

Address for Correspondence / Yazışma Adresi: Barış Sevinç E.mail: drbarissevinc@gmail.com DOI: 10.5152/tpd.2016.4623

CCopyright 2016 Turkish Society for Parasitology - Available online at www.tparazitolderg.org

CTelif hakkı 2016 Türkiye Parazitoloji Derneği - Makale metnine www.tparazitolderg.org web sayfasından ulaşılabilir. 


\section{INTRODUCTION}

Echinococcosis (hydatidosis or hydatid disease) is a zoonosis caused by the larval (metacestode) stages of cestodes (flat worms) belonging to the genus Echinococcus and the family Taeniidae (1). The most common location for the development of hydatid cysts is the liver (50\%-70\%) (2).

Surgery and percutaneous aspiration-injection-re-aspiration (PAIR) are widely accepted treatment modalities for hepatic hydatid cysts. However, in biliary fistulas and hydatid cysts with biliary rupture, endoscopic retrograde cholangiopancreaticography (ERCP) is widely used (3). ERCP acts as a minimally invasive rescue method for the biliary complications of both the hydatid cysts and treatment modalities.

In the postoperative period, a residual hydatid cyst cavity is a major problem because it can get infected, and it is difficult to discriminate from recurrence. Therefore, several methods to obliterate the entire cavity have been identified.

The aim of this study was to identify the role of different treatment modalities for the obliteration of the hydatid cyst cavity.

\section{METHODS}

Patients treated for hydatid cysts between January 2009 and December 2013 were evaluated in the study. Data were collected from hospital records. Because of the retrospective nature of the study, ethical committee approval and patient consent were not obtained. Patients' age, gender, cyst location, cyst number, and cyst diameter were recorded. Based on operation and PAIR records, features of the cysts, especially data regarding communication with the biliary system, were recorded. A total of 235 patients with complete records were included in the study.

All patients included in the study were called for a follow-up visit. At the visit, the presence of a residual cyst cavity was evaluated by ultrasonography (USG) or computed tomography (CT). The imaging modality was chosen according to previous records, and the same modality was used for follow-up. The ratio of the decrease in hydatid cyst diameter was calculated.

Patients were evaluated in three groups: PAIR, surgery, and ERCP. All of the ERCP patients had biliary rupture, and they were treated with only ERCP+endoscopic sphinchterotomy (ES). The ratio of the decrease in hydatid cyst diameter and the effect of biliary rupture on cyst shrinkage were evaluated.

\section{Statistical analysis}

For statistical analysis, IBM SPSS Statistics 20.0 (IBM Inc.; California, USA) software was used. Student's T test, one-way ANOVA, and chi-square tests were used when available. For subgroup analysis, Tukey's subgroup analysis test was used. The statistical significance level was accepted to be 0.05 .

\section{RESULTS}

Ninety-five (40.4\%) males and 140 (59.5\%) females were included in the study. The mean age of the patients was $44.8 \pm 19.1$ years, and the groups were similar in terms of mean age $(p>0.05)$. There were 99 (42.1\%) patients in the surgery group, 122 (51.9\%) patients in the PAIR group, and $14(4.1 \%)$ patients in the ERCP group. The median follow-up period of the study was 12 (2-36) months, and the groups were similar in terms of median follow-up period.
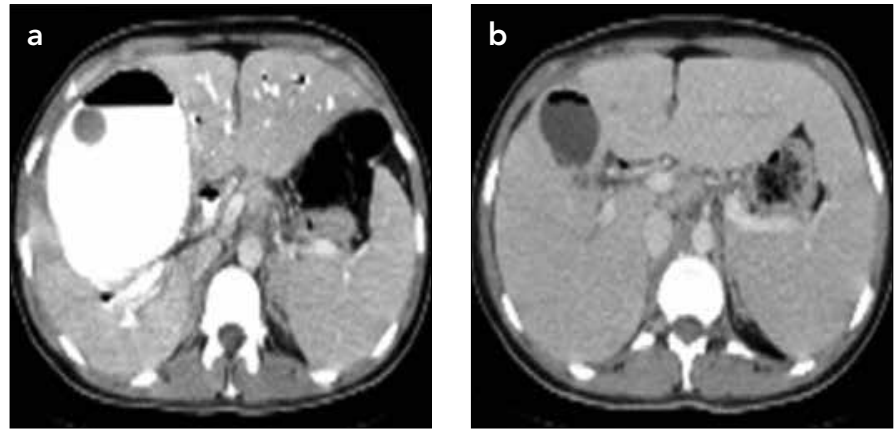

Figure 1. a, b. Pre-ERCP and 6-month follow-up CT scans of a hydatid cyst. (a) Preoperative CT scan showing a hydatid cyst in the right lobe of the liver (b) The same cyst at 6 months after treatment with only ERCP+ES

ERCP: endoscopic retrograde cholangiopancreaticography; CT: computed tomography; ERCP+ES: endoscopic retrograde cholangiopancreaticography+endoscopic sphincterotomy

Table 1. The mean ratio of the decrease in hydatid cyst cavity size according to groups

\begin{tabular}{|c|c|c|c|}
\hline & & Mean \pm SD & $p$ \\
\hline Surgery & 99 & $43.2 \pm 31.7$ & \multirow{3}{*}{$<0.001$} \\
\hline PAIR & 122 & $32.3 \pm 27.1$ & \\
\hline ERCP & 14 & $63.6 \pm 19.7$ & \\
\hline Total & 235 & $37.9 \pm 30.3$ & \\
\hline
\end{tabular}

Table 2. The mean ratio of the decrease in hydatid cyst cavity size according to groups

\begin{tabular}{|l|c|c|c|}
\hline \multirow{2}{*}{ Group (a) } & Group (b) & $\begin{array}{c}\text { Mean } \\
\text { difference } \\
(\mathbf{a}-\mathbf{b})\end{array}$ & $\mathbf{P}$ \\
\hline \multirow{2}{*}{ Surgery } & PAIR & 10.9 & 0.015 \\
\cline { 2 - 4 } & ERCP & -20.3 & 0.03 \\
\hline \multirow{2}{*}{ PAIR } & Surgery & -10.9 & 0.015 \\
\cline { 2 - 4 } & ERCP & -31.3 & 0.001 \\
\hline \multirow{2}{*}{ ERCP } & Surgery & 20.3 & 0.03 \\
\cline { 2 - 4 } & PAIR & 31.3 & 0.001 \\
\hline \multicolumn{3}{|l|}{$\begin{array}{l}\text { ERCP: endoscopic retrograde cholangiopancreaticography, PAIR: } \\
\text { percutaneous aspiration-injection-re-aspiration }\end{array}$} \\
\hline
\end{tabular}

Before the procedures, the mean cyst diameter was $89.7 \pm 33.5$ $\mathrm{mm}$. The groups were similar in terms of mean cyst diameter ( $p>0.05)$. At follow-up, the mean cyst diameter decreased to $53.2 \pm 30.1 \mathrm{~mm}$. In the ERCP group, the mean diameter of the residual cyst cavity was significantly lower than that of the other groups $(p=0.003)$

In the ERCP group, at the 6-month follow-up, the hydatid cyst cavity had disappeared in seven of 14 patients (50\%). Figure 1 shows pre-ERCP and 6-month follow-up CT images of the hydatid cyst.

The mean ratio of the decrease in hydatid cyst diameter was found to be $37.9 \% \pm 30.3 \%$. It was $43.2 \% \pm 31.7 \%$ in the surgery 
Table 3. Association between biliary communication and the decrease in hydatid cyst cavity size

\begin{tabular}{|l|c|c|c|c|}
\hline \multirow{2}{*}{ Surgery } & $\begin{array}{c}\text { Biliary } \\
\text { communication }\end{array}$ & $\begin{array}{c}\text { Mean decrease } \\
\text { in hydatid cyst } \\
\text { cavity size (\%)* }\end{array}$ & SD & \multirow{2}{*}{ P } \\
\cline { 2 - 4 } & Yes & 48,4 & 31,95 & \multirow{2}{*}{0,657} \\
\hline \multirow{2}{*}{ PAIR } & No & 42,8 & 31,90 & \\
\cline { 2 - 4 } & Yes & 55,1 & 28,84 & \multirow{2}{*}{0,013} \\
\hline \multirow{2}{*}{ Total } & No & 30,7 & 26,39 & \\
\cline { 2 - 4 } & Yes & 57,7 & 25,7 & \multirow{2}{*}{0,004} \\
\hline
\end{tabular}

*In the ERCP group, all cysts were communicating with the biliary tree. The ERCP group was excluded from this analysis. PAIR: percutaneous aspirationinjection-re-aspiration

group, $32.3 \% \pm 27.1 \%$ in the PAIR group, and $63.6 \% \pm 19.7 \%$ in the ERCP group (Table 1). The mean ratio of hydatid cyst shrinkage was significantly higher in the ERCP group $(p<0.001)$. On subgroup analysis, the mean shrinkage ratio was higher in the surgery group than in the PAIR group ( $p=0.015$; Table 2).

The mean shrinkage ratio was significantly higher in hydatid cysts with biliary fistulization than in non-fistulizing cysts $(57.7 \% \pm 25.7 \%$ and $36.2 \% \pm 29.5 \%$, respectively). In case of biliary fistulization, the shrinkage of hydatid cysts was faster ( $p=0.004$; Table 3 ).

\section{DISCUSSION}

In the treatment of hydatid cysts, obliteration of the cyst cavity is an important problem. As the least traumatic method, total cystectomy is commonly used. However, it has complications like infection, sinus formation, recurrence, and dissemination (3). Omentoplasty, capitonnage, simple closure, deroofing, and tube drainage are the most commonly used techniques for residual cavity management (4-10). The main limitations of these techniques are inapplicability for extremely large hydatid cysts in omentoplasty, injury to blood vessels and biliary tract in capitonnage, intestinal entrapment in the residual cavity in deroofing, and risk of spillage and anaphylactic shock in percutaneous aspiration under radiologic guidance (11).

For hydatid cysts with biliary rupture, the preferred approach has been surgery $(12,13)$. However, an increasing number of reports have been published regarding endoscopic treatment for hydatid cysts with biliary rupture, and nowadays, ERCP has emerged as a safe treatment method (3, 14-20). In our report, 14 cases were treated with only ERCP+ES.

To the best of our knowledge, no studies have evaluated the residual cavity diameter after the treatment of hydatid cysts using ERCP. ERCP is widely used for treating the complications of hydatid cysts, such as common bile duct obstruction, cholangitis, and biliary fistula (7-10).

The main limitations of this report are the retrospective design and the small number of cases treated with only ERCP+ES. However, as a hydatid cyst with biliary communication is a rare condition, the only case reports in the literature are regarding the endoscopic treatment of hydatid cysts.
In this report, three different treatment modalities were evaluated in terms of obliteration of the cyst cavity. On subgroup analysis, the highest cavity shrinkage was found in the ERCP group. ERCP provided faster hydatid cyst shrinkage and even disappearance of the residual cavity in $50 \%$ of cases.

Moreover, irrespective of treatment modality, hydatid cysts with biliary communication obliterate faster. Faster obliteration of the hydatid cyst cavity can be related to contamination with bile. Likewise, decreased biliary pressure can also be an important factor for cavity obliteration.

In hydatid cysts with biliary communication, ERCP+ES can be safely used for primary treatment. Because hydatid cysts can obliterate faster with $\mathrm{ERCP}+\mathrm{ES}$ than with other treatment modalities, there is a need for further studies to identify the reason for this accelerated obliteration.

Ethics Committee Approval: Ethics committee approval was not received due to the retrospective nature of this study.

Informed Consent: Written informed consent was not received due to the retrospective nature of this study.

Peer-review: Externally peer-reviewed.

Author Contributions: Concept - B.S., Ö.K.; Design - B.S., G.Ş.; Supervision - Ö.K., N.A.; Materials - S.B., S.S., B.S.; Data Collection and/or Processing - B.S., N.A.; Analysis and/or Interpretation - B.S., Ö.K., S.S.; Literature Review - G.Ş., S.S.; Writing - B.S., S.S., N.A.; Critical Review Ö.K., S.B.

Conflict of Interest: No conflict of interest was declared by the authors.

Financial Disclosure: The authors declared that this study has received no financial support.

Etik Komite Onayı: Çalışmanın retrospektif tasarımından dolayı etik komite onayı alınmamıştır.

Hasta Onamı: Çalışmanın retrospektif tasarımından dolayı hasta onamı alınmamıştır.

\section{Hakem Değerlendirmesi: Dış bağımsız.}

Yazar Katkıları: Fikir - B.S., Ö.K.; Tasarım - B.S., G.Ş.; Denetleme - Ö.K., N.A.; Malzemeler - S.B., S.S., B.S.; Veri Toplanması ve/veya Iş̧lemesi - B.S., N.A.; Analiz ve/veya Yorum - B.S., Ö.K., S.S.; Literatür Taraması - G.Ş., S.S.; Yazıyı Yazan - B.S., S.S., N.A.; Eleştirel İnceleme - Ö.K., S.B.

Çıkar Çatışması: Yazarlar çıkar çatışması bildirmemişlerdir.

Finansal Destek: Yazarlar bu çalışma için finansal destek almadığını belirtmiştir.

\section{REFERENCES}

1. Milicevic M, 2007. Echinococcal Cysts: Cause, Diagnosis, Complications, and Medical and Surgical Treatment. Mastery of Surgery, Fischer JE, 5th Edition, Lippincott Williams \& Wilkins, p. 1044-7.

2. Brunetti E, Kern P, Vuitton DA, Writing Panel for the WHO-IWGE. Expert consensus for the diagnosis and treatment of cystic and alveolar echinococcosis in humans. Acta Trop 2010; 114: 1-16. [CrossRef]

3. Somani SK, Srivastava AP. Resolution of hepatic hydatid cyst with biliary communication with ERCP. J Gastroint Dig Syst 2012; 2:114 [CrossRef]

4. Sayek I, Onat D. Diagnosis and treatment of uncomplicated hydatid cyst of the liver. World J Surg 2001; 25: 21-7. [CrossRef] 
5. Köksal N, Müftüoglu T, Günerhan Y, Uzun MA, Kurt R. Management of intrabiliary ruptured hydatid disease of the liver. 2001; 48: 1094-6.

6. Kayaalp C, Sengul N, Akoglu M. Importance of cystcontent in hydatid liver surgery. Arch Surg 2002; 137: 159-63. [CrossRef]

7. Junghanss T, da Silva AM, Horton J, Chiodini PL, Brunetti E. Clinical management of cystic echinococcosis: state of the art, problems, and perspectives. Am J Trop Med Hyg 2008; 79: 301-11.

8. Moro P, Schantz PM. Echinococcosis: a review. Int J Infect Dis 2009; 13: 125-33. [CrossRef]

9. Safioleas MC, Misiakos EP, Kouvaraki M, Stamatakos MK, Manti CP, Felekouras ES. Hydatid disease of the liver: a continuing surgical problem. Arch Surg 2006; 141: 1101-8. [CrossRef]

10. Kama NA, Şahin M, Göçmen E, Bayrak M, Kulaçoğlu H, Akat AZ. The results of surgical techniques in hepatic hydatidosis: treatment with drain ageversustreatmentwithoutdrainage-a 6-year experience. Journal of the Royal College of Surgeons of Edinburgh 1998; 43: 254-6.

11. Losanoff JE, Richman BW, Jones JW. Organ-sparing surgical treatment of giant hepatic hydatid cysts. Am J Surg 2004; 187: 288-90. [CrossRef]

12. Erzurumlu K, Dervisoglu A, Polat C, Senyurek G, Yetim I. Intrabiliary rupture: An algorithm in the treatment of controversial complication of hepatic hydatidosis. World J Gastroenterol. 2005; 11: 2472-2476. [CrossRef]
13. Al-Akayleh A. Frank intrabiliary rupture of hydatid hepatic cyst: diagnosis and treatment. East Mediterr Health J 2000; 6: 522-55.

14. Al Karawi MA, Mohamed AR, Yasawy I, Haleem A. Non-surgical endoscopic transpapillary treatment of ruptured echinococcus liver cyst obstructing the biliary tree. Endoscop. 1987; 19: 81-3. [CrossRef]

15. Shemesh E, Klein E, Abramowich D, Pines A. Common bile duct obstruction caused by hydatid daughter cysts--management by endoscopic retrograde sphincterotomy. Am J Gastroenterol 1986; 81: 280-2.

16. Al Karawi MA, el-Shiekh Mohamed AR, Yasawy MI. Advances in diagnosis and management of hydatid disease. Hepatogastroenterology 1990; 37: 327-31.

17. Khoshbaten M, Farhang S, Hajavi N. Endoscopic retrograde cholangiography for intrabiliary rupture of hydatid cyst. 2009; 21: 277-9.

18. Bilsel Y, Bulut T, Yamaner S, Buyukuncu Y, Bugra D, Akyuz A, et al. ERCP in the diagnosis and management of complications after surgery for hepatic echinococcosis. Gastrointest Endosc 2003; 57: 2103. [CrossRef]

19. Dolay K, Ahbulut S. Role of endoscopic retrograde cholangiopancreatography in the management of hepatic hydatid disease. World J Gastroenterol 2014; 20: 15253-61. [CrossRef]

20. Hafeez M, Hussain T, Salamat A, Hassan F, Farooq A, Saeed F. Ruptured hydatidcyst in biliarytract. J Coll Physicians Surg Pak 2012; 22: 663-5. 